\title{
Citra KPK Pada Kasus Korupsi Menteri Juliari Batubara (Analisis Wacana Kritis Fairclogh)
}

\author{
Agung Pangeran Bungsu \\ UIN Sunan Kalijaga Yogyakarta \\ agungpangeran0@gmail.com
}

\begin{abstract}
The corruption that occurs in Indonesia seems unending. Starting from officials in the legislative body, the executive and even the judiciary, they are often dragged into corruption cases. The KPK as an independent institution in handling corruption cases seems to be an institution that other institutions fear and avoid. Even though the existence of the KPK aims to ensure a clean government. The media as the mouthpiece of the government is sometimes misused for political and corporate interests, this is also done in reporting about the KPK. This research will try to see how the two major media in Indonesia, namely Republika and Tempo, in building discourse construction. In this case, it will be reviewed how Republika and Tempo build an image for the KPK. This research method uses methodological and theoretical approaches. The descriptive methodological analysis approach was chosen to be able to see theoretically Fairclogh's critical discourse analysis. The existing discourse is analyzed by three objects through (a) text, (b) the dimension of discourse, (c) the sociocultural dimension. Research results from the three objects of Fairclogh's study show that Republika provides a negative image for the KPK, while Tempo provides a positive image for the KPK.
\end{abstract}

Keywords: KPK Image, Corruption Minister Juliari Batubara, Fairclogh's Critical Discourse Analysis

Abstrak. Korupsi yang terjadi di Indonesia seakan tak ada hentinya. Dimulai dari pejabat yang ada di lembaga legislatif, eksekutif bahkan lembaga yudikatif juga kerap terseret kasus korupsi. KPK sebagai lembaga independen dalam penanganan kasus korupsi seolah menjadi lembaga yang ditakuti dan dihindari oleh lembaga lainnya. Padahal keberadaan KPK bertujuan untuk memastikan pemerintahan yang bersih. Media sebagai corong pemerintah terkadang sering disalahgunakan untuk kepentingan politik dan korporasi, hal ini juga dilakukan dalam pemberitaan tentang KPK. Penelitian ini akan mencoba melihat bagaimana dua media besar yang ada di Indonesia yaitu Republika dan Tempo dalam membangun konstruksi wacana. Dalam hal ini akan ditinjau bagaimana Republika dan Tempo membangun citra bagi KPK. Metode penelitian ini menggunakan pendekatan metodologis dan teoritis. Pendekatan metodologis deskriptif analisis dipilih untuk dapat melihat secara teoritis analisis wacana kritis Fairclogh. Wacana yang ada dianalisis dengan tiga objek melalui (a)teks, (b) dimensi kewacanaan, (c) dimensi sosiokultural. Hasil penelitian dari ketiga objek kajian Fairclogh menunjukkan bahwa Republika memberikan citra negatif bagi KPK sedangkan Tempo memberikan citra yang positif bagi KPK.

Kata Kunci: Citra KPK, Korupsi Menteri Juliari Batubara, Analisis Wacana Kritis Fairclogh 


\section{PENDAHULUAN}

Media memiliki pengaruh yang sangat kuat di lingkungan masyarakat, terlebih bagi media online. Suatu media mampu membangun sebuah konstruksi pemikiran baru bagi masyarakat. Perubahan yang ada ternyata telah terjadi sejak tahun 1990 an, dimana media cetak dan media massa tradisional telah dikorbankan untuk menyambut media baru atau yang lebih dikenal dengan media online (Brossard \& Scheufele, 2013). Hal ini terjadi hampir di seluruh penjuru dunia, meskipun perubahan perilaku masyarakat Indonesia baru saja benar-benar dirasakan sejak beberapa dekade yang lalu. Pengaruh lain dari media adalah untuk menggiring opini publik dengan argumen-argumen yang disampaikan. Oleh karenanya tidak heran apabila para penguasa berlomba-lomba untuk menguasai media yang ada di tengah masyarakat, tentunya dengan tujuan pencitraan, propaganda bahkan untuk menutupi kesalahan yang memang benar-benar terjadi. Dalam proses pemberitaan kasus korupsi misalnya, sudah menjadi rahasia bagi publik apabila ada media yang tidak memberikan informasi yang sama tentang korupsi. Meskipun pada waktu itu korupsi adalah isu yang tengah hangat di tengah masyarakat, hal ini bertujuan untuk tetap berupaya menjaga citra para pejabat publik di hadapan khalayak.

Istilah korupsi tampaknya bukanlah istilah yang asing di telinga masyarakat Indonesia, hal ini disebabkan karena kasus korupsi yang terjadi di Indonesia tidak terhitung jumlahnya. Dimulai dari kalangan pejabat di lembaga legislatif, eksekutif bahkan kasus korupsi juga kerap terjadi pada para pejabat di lembaga yudikatif. Kasus-kasus yang terjadi pada kalangan elite ini sangat mencengangkan, pasalnya para pejabat yang memegang tampuk kekuasaan yang semestinya bekerja menunaikan amanat dari rakyat kini menyalahgunakan kekuasaan yang telah diberikan. Kekuasaan dijadikan alat untuk menindas masyarakat kecil, sampai pada tujuan akhirnya adalah 
kekuasaan digunakan sebagai alat untuk memperkaya diri, keluarga bahkan untuk memperkaya partai pengusung jabatan strategis yang dimiliki.

Tidak berhenti pada lembaga-lembaga besar seperti lembaga legislatif, eksekutif bahkan pada lembaga yudikatif saja, kasus korupsi juga kerap terjadi di jajaran para menteri yang merupakan pembantu presiden di lembaga eksekutif. Adapun tugas pokok para menteri adalah membantu presiden dalam melaksanakan tugas dan amanat yang diberikan oleh rakyat. Menteri yang dipilih ada yang berasal dari afiliasi partai tertentu bahkan dan ada juga dari kalangan non partai. Kualifikasi yang ditetapkan berdasarkan hubungan politik atau memang mereka yang memiliki kapasitas di bidangnya. Akan tetapi janji-janji politik selama masa kampanye memang tidak dapat dihindari, kursi-kursi serta jabatan strategis yang telah dijanjikan sebelum pilpres haruslah ditepati. Hal inilah yang menjadi sebab kasus korupsi terjadi di kalangan para menteri dan juga pada kalangan pejabat strategis di negara Indonesia.

Penanganan setiap kasus korupsi yang terjadi di Indonesia dilakukan oleh satu lembaga independen yang disebut dengan KPK (Komisi Pemberantasan Korupsi). Bukanlah suatu beban amanah yang mudah bagi KPK sejak reformasi melakukan pemberantasan korupsi di negara seluas Indonesia, tentunya ini amanat yang sangatlah berat. Pasalnya KPK dalam hal ini terkadang harus berhadapan langsung dengan para pemangku jabatanjabatan penting yang ada di jajaran pemerintahan. Ditambah lagi apabila suatu kasus tertentu yang memiliki hubungan dengan aparat penegakan hukum, tentunya akan sulit bagi KPK untuk tetap dapat berdiri tegak dalam menjalankan amanat UUD 1945. Independensi, transparansi serta profesionalitas dalam menjalankan tugas merupakan nilai luhur yang harus terus dijaga oleh KPK. Terlebih komponen yang bergerak menjadi bagian dalam menjalankan fungsi KPK berasal dari berbagai kalangan ada, tentunya 
kinerja dan komitmen dari KPK untuk menegakkan korupsi akan selalu menjadi sorotan dari masyarakat luas.

Kasus korupsi di jajaran menteri selama pemerintahan presiden Jokowi terbilang banyak jumlahnya, secara keseluruhan menteri yang ditetapkan sebagai tersangka oleh KPK dalam kasus tindak pidana korupsi merupakan menteri yang berasal dari berbagai afiliasi partai besar di Indonesia. Diantaranya kasus mantan menteri sosial Idrus Marham berasal dari partai Golkar (Golongan Karya) yang terseret kasus korupsi saat masa bakti kabinet "Indonesia Maju" tahun 2014-2019. Kemudian dilanjutkan lagi kasus korupsi mantan menteri pemuda dan olahraga Imam Nahrawi berasal dari partai PKB (Partai Kebangkitan Bangsa) yang juga terseret kasus korupsi saat masa bakti kabinet "Indonesia Maju" tahun 2014-2019. Dilanjutkan kasus korupsi berikutnya yang belum lama menyeret mantan menteri kelautan dan perikanan yaitu Edhy Prabowo, ia berasal dari partai Gerindra (Gerakan Indonesia Raya) yang terseret kasus korupsi saat masa bakti kabinet "Indonesia Maju" tahun 2019-2024. Kasus yang cukup fenomenal adalah kasus korupsi yang menjerat menteri sosial seorang politikus PDIP atau (Partai Demokrasi Indonesia Perjuangan) Juliari Batubara di masa pemerintahan kabinet "Indonesia Maju” jilid 2 (Prabawati, 2020).

Tulisan ini akan melihat kasus korupsi yang terakhir kali terjadi di penghujung tahun 2020. Kasus korupsi yang akan dikaji adalah kasus korupsi yang menjerat menteri Juliari Batubara. Hal ini disebabkan karena menteri Juliari diusung oleh partai pemerintah sendiri yang tidak lain adalah PDIP atau (Partai Demokrasi Indonesia Perjuangan). Sebuah pemandangan yang tidak etis rasanya di masa sulit dalam menangani pandemi covid-19 harusnya para menteri bahu-membahu menyelesaikan permasalahan, akan tetapi masih saja ditemukan pejabat yang melakukan tindakan merugikan rakyat. Terkait hal itu, tulisan ini akan mencoba membedah bagaimana media online Tempo dan Republika edisi Desember 2020 dalam membangun citra bagi KPK 
selaku lembaga penanganan kasus korupsi di Indonesia. Kedua media ini dipilih dengan alasan bahwa media ini mampu tetap eksis di tengah pertarungan media baru lainnya, tetap mampu mempertahankan ideologi serta idealismenya di tengah tekanan politik dan kepentingan penguasa. Wacana yang ada akan dianalisis dengan menggunakan pendekatan analisis wacana kritis Fairclogh. Hal ini tentu saja sangat menarik karena konstruksi analisis yang digagas oleh Fairclogh yang mencoba melihat sebuah wacana dari berbagai objek yang ada. Dimana fokus utama analisis wacana kritisnya adalah pada efek hubungan kekuasaan dan ketidaksetaraan sehingga menimbulkan kesalahan sosial, khususnya pada aspek diskursif dari hubungan kekuasaan dan ketidaksetaraan (Fairclough, 2010).

Pendekatan penelitian yang dipilih untuk tulisan ini adalah dengan menggunakan pendekatan metodologis dan teoritis. Kemudian akan dipilih pendekatan metodologis deskriptif analisis untuk dapat melihat secara teoritis analisis wacana kritis AWK atau yang sering disebut dengan critical discourse analysis $\mathrm{CDA}$.

Wacana yang ada akan dianalisis dengan tiga objek kajian Fairclogh, diantaranya melalui (a) teks, (b) praktik wacana discourse practice, (c) praktik sosiokultural (Fairclough, 2010). Data yang digunakan adalah data yang bersumber dari media online Tempo dan Republika edisi pemberitaan Desember 2020. Analisis data yang ada dimulai dengan 3 tahapan. Pertama teks, dianalisis melalui pendekatan linguistik yang mencakup bentuk formal seperti kosakata, tata bahasa, dan struktur tekstual. Kedua dimensi wacana, akan melihat bagaimana sebuah teks diproduksi, dikonsumsi bahkan didistribusikan. Ketiga dimensi sosiokultural, dianalisis mulai dari tingkatan level situasional, institusional dan level sosial (Munfarida, 1970). 


\section{HASIL DAN PEMBAHASAN}

\section{Dimensi Tekstual}

Tahapan dimensi tekstual merupakan tahapan awal dalam analisis wacana kritis Fairclogh, dimulai dari representasi pemilahan anak kalimat (klausa), representasi kombinasi anak kalimat (klausa) dan representasi dalam rangkaian antarkalimat. Berdasarkan analisis tekstual terlihat bagaimana media membangun citra bagi KPK selaku lembaga pemberantasan korupsi yang menjerat partai penguasa lewat opini yang tuliskan. Berikut analisis wacana yang akan dilihat oleh publik bagaimana media memberitakan kasus korupsi menteri Juliari Batubara.

Pertama, berita yang ditulis Republika sebagai berikut:

"Menteri Sosial Juliari Peter Batubara ditetapkan sebagai tersangka. Miris dengan kenyataan ini, korupsi seperti menjadi budaya baru dalam tataran pemangku jabatan negara. Dana yang seharusnya digunakan untuk kepentingan rakyat yang terdampak pandemi, malah digunakan untuk memenubi kebutuban pejabat tanpa melihat kehalalan dalam mendapatkannya. Negara harus membuat aturan baru yang mampu menghilangkan korupsi yang menggurita, serta menegakekan bukum positifyang berkeadilan dan tegas. Dengan demikian, akan memberi efek, jera bagi pelaku korupsi. Seharusnya, para pemangku jabatan mengbindarkan diri dari praktik korupsi. Maka sejatinya, sistem dengan aturan yang berasal dari Sang Khalik yang mampu menyelesaikan permasalaban korupsi ini. (Mensos Korupsi Dana Bansos, Budaya Pejabat Negara ("Mensos Korupsi Dana Bansos, Budaya Pejabat Negara," 2020).

Kedua, berita yang ditulis Tempo sebagai berikut:

"Komisi Pemberantasan Korupsi tidak boleh menghentikan penyidikan kasus korupsi proyek bantuan sosial (bansos) hanya pada mantan Menteri Sosial, Juliari Peter Batubara. Kesaksian para pelaku dan bukti-bukti lain menunjukkan bahwa Juliari tidak menikmati sendiri fulus ratusan miliar rupiah hasil korupsinya. Ada indikasi kuat sejumlah fungsionaris Partai Demokrasi Indonesia Perjuangan ikut menyalurkan duit haram itu untuk pemenangan beberapa calon dalam pemiliban kepala daerah yang baru usai. Karena itu, penahanan Juliari pada 6 Desember lalu barus dijadikan pintu masuk untuk mengungkap lebar jejaring pelaku korupsi dana bansos. KPK tidak boleh gentar, meski berbadapan dengan partai penguasa. Korupsi dana bantuan untuk masyarakat yang terempas krisis ekonomi akibat pandemi jelas 
merupakan kejahatan level tertinggi. Pelakunya tak hanya merugikan keuangan negara, tapi juga mengancam bidup banyak orang. Karena itulah berbagai tanda ketidakberesan penyaluran bantuan sosial seolah-olah diabaikan begitu saja. Sistem pencegahan korupsi tak berjalan. Publik patut mengapresiasi kerja keras penyidik komisi antikorupsi yang telaten mengumpulkan bukti demi bukti yang berujung pada penahanan Juliari ("Jangan Berhenti Di Menteri Juliari," 2020).

Dapat dilihat dua sisi pemberitaan yang dilakukan oleh dua media diatas yakni media online Republika dan Tempo memiliki gaya yang cukup khas dalam memberitakan kasus korupsi yang menjerat pejabat pemerintah. Kalimat pembuka dalam teks wacana Republika dimulai dengan "Mensos Korupsi Dana Bansos, Budaya Pejabat Negara" terkesan mendukung perilaku korupsi yang dilakukan oleh rezim atau penguasa, meskipun terdapat tujuan lain dari wartawan sendiri tentunya. Subjek dalam judul diatas adalah mensos sendiri yaitu Juliari Batubara, adapun predikat judul tersebut adalah korupsi. Kemudian objek dalam judul kalimat tersebut adalah bansos. Diikuti dengan hubungan perluasan kata "Budaya Pejabat Negara" seolah membenarkan tindak pidana korupsi yang terjadi. Kalimat yang dipilih sebagai judul tersebut bisa saja akan menimbulkan penafsiran-penafsiran yang beragam dari para pembaca. Frasa yang dipilih tentunya kurang tepat, hal ini seolah menjadikan korupsi sebagai sesuatu yang memang lazim terjadi karena yang berbuat adalah para pejabat.

Pemilihan kata yang digunakan oleh Republika terbilang sangat berhati-hati. Kata "pemangku jabatan negara" pada kalimat kedua menunjukan arah kepada rezim atau penguasa. Tidak lain adalah presiden yang menunjuk para menteri untuk dapat membantunya dalam menyelesaikan tugas kenegaraan. Dilanjutkan pada kosakata yang terdapat di kalimat ketiga yaitu kata "kehalalan" merupakan pemilihan kata yang cukup santun dengan pemberitaan kasus korupsi sekelas menteri, wartawan bisa saja menggunakan antonim atau lawan kata "kehalalan" dengan kata "keharaman" akan tetapi hal ini tidak dilakukan dengan tujuan berita ini cukup hangat 
apabila dikonsumsi berbagai kalangan. Dilanjutkan kosa kata pada kalimat keempat "negara harus membuat aturan baru" yang semestinya tidak perlu lagi disebutkan karena negara Indonesia telah memiliki perundang-undangan yang mengatur tentang tindak pidana korupsi. Kemudian kata "menggurita" pada kalimat keempat ini terkesan sedikit ambigu, wartawan Republika seolah tidak berani mengatakan secara gamblang makna menggurita ini adalah kasus korupsi yang melibatkan siapa dan siapa sehingga kata menggurita sejatinya membutuhkan proses elaborasi pada kalimat berikutnya. Pada kalimat keenam terdapat kosa kata "sang khalik" seperti terlalu berlebihan. Pemilihan kata ini seolah memasrahkan bagaimana kelanjutan hukum yang akan dilangsungkan bagi menteri sosial. Dengan kata lain wartawan Republika seolah tidak menganggap bahwa Indonesia memiliki satu lembaga independen dalam penanganan kasus korupsi yaitu KPK.

Dalam teks pula tidak ditemukan lagi kata "Juliari Batubara" selain hanya diawal pembuka kalimat pertama. Pronomina yang digunakan untuk subjek adalah mensos yang hanya disebutkan satu kali dalam kalimat pembuka. Hal ini menyebabkan pembaca larut dalam tulisan yang mencoba menggiring pembaca ke arah yang diinginkan oleh wartawan. Isi teks secara keseluruhan sangat general. Dimulai dari pembahasan tentang aturan hukum yang berlaku, tindakan preventif yang seharusnya diambil oleh pejabat sampai pada kalimat keputusasaan pada hukum yang berlaku. Konstruksi yang dibangun mengakibatkan pembaca seolah tidak dapat benar-benar merasakan berita yang ada ditujukan kepada mantan menteri sosial.

Kalimat-kalimat yang dibangun oleh wartawan Republika sangat berfokus pada kronologi kejadian yang ada, sehingga dalam tingkatan tekstual harapan wartawan seolah tidak mengarah dan tertuju kepada satu lembaga, partai atau bahkan institusi pemerintah sekalipun. Kata "pemangku jabatan" dan "pejabat negara" adalah diksi yang sangat positif dalam sebuah pemberitaan. Pembaca seolah tidak dibiarkan fokus dan terprovokasi pada 
siapa yang melakukan korupsi. Siapa saja yang telah terlibat dalam kasus ini, bahkan satu hal yang sangat disayangkan, tidak sedikitpun teks memberikan penjelasan tentang lembaga yang berhasil mengungkapkan kasus korupsi. Padahal informasi yang dibangun oleh media yang ada tentunya berdasarkan dari hasil investigasi dan penyelidikan lembaga yang mengungkap kasus korupsi yaitu KPK. Dalam teks pula tidak menjelaskan secara detail siapa yang seharusnya diperiksa sehingga elaborasi dari satu kalimat hingga kalimat berikutnya sangat minim.

Kalimat penutup dalam konstruksi teks yang ada seolah tidak memberikan harapan pada pemegang kekuasaan. Kalimat terakhir "sistem dengan aturan yang berasal dari Sang Khalik yang mampu menyelesaikan permasalahan korupsi ini" seolah mengecilkan fungsi lembaga-lembaga yang ada di negara Indonesia. Penggunaan kata "Sang Khalik" atau kata tuhan adalah pemilihan kata yang kurang baik. Sehingga para pemegang fungsi penegak hukum tidak bersungguh-sungguh dalam mengusut tuntas kasus korupsi yang dilakukan oleh mantan menteri sosial Juliari Batubara.

Dalam tinjauan dimensi tekstual yang ada dapat dilihat bahwa Republika memiliki ideologi yang cenderung demokratis, tidak terlalu mementingkan substansi pemberitaan. Kata-kata, frasa serta kalimat yang dibangun mengesankan bahwa media haruslah berada ditengah. Tidak berpihak kepada rezim atau penguasa akan tetapi juga tidak berada pada oposisi sebagai media sepenuhnya. Meskipun secara garis besar dari tinjauan tekstual wacana diatas dapat disimpulkan bahwa Republika memang mampu menenangkan pembaca dengan diksi-diksi yang dipilih, sehingga tulisantulisan yang akan dikirim nantinya juga tetap dapat diterima oleh rezim ataupun khalayak selaku pembaca. Sebagai simpulan dapat ditemukan bahwa dari konstruksi wacana yang terdapat di media Republika memberikan citra negatif bagi KPK selaku lembaga penegakan hukum kasus korupsi. Bahkan 
tidak ada satu kata "KPK" pun yang terlihat dalam bangunan wacana teks Republika.

Berbeda dengan ideologi yang dimiliki media Republika, media Tempo mencoba memposisikan dirinya sebagai media yang benar-benar mencerdaskan pembaca. Subjek pada kalimat pertama dimulai dengan Komisi Pemberantasan Korupsi dilanjutkan dengan predikatnya yaitu tidak boleh menghentikan penyidikan dan objeknya kasus korupsi proyek bantuan sosial (bansos). Kalimat negatif pada awal pembuka kalimat yang ada tentu saja akan menimbulkan perhatian dari pembaca. Kata "tidak boleh menghentikan" disini merupakan wujud dari harapan besar yang ditumpukan kepada lembaga Komisi Pemberantasan Korupsi yang tengah mendalami kasus menteri Juliari. Pronomina yang digunakan sebagai pengganti subjek cukup menekan para pembaca dengan sapaan langsung "Juliari". Padahal wartawan Tempo sebenarnya bisa saja memilih kosa kata lainnya yang lebih santun seperti "mantan menteri sosial" atau juga dapat menggunakan kata "eks mensos". Hal ini menunjukkan bahwa Tempo memiliki ideologi dan gaya penulisan yang berbeda dengan media lainnya. Masih berada pada kalimat kedua, pemilihan frasa "fulus ratusan miliar rupiah" cukup menarik. Kata "fulus" berasal dari bahasa Arab yang berarti "uang". Diksi ini sengaja dipilih wartawan Tempo untuk menarik minat para pembaca. Dengan demikian, meskipun tidak semua orang mengetahui makna "fulus" secara bahasa yang sebenarnya, apabila diselaraskan dengan frasa tertentu maka seperti frasa "ratusan miliar rupiah hasil korupsinya" maka pembaca akan memahami makna yang sebenarnya.

Dilanjutkan pada kalimat ketiga, "Ada indikasi kuat sejumlah fungsionaris Partai Demokrasi Indonesia Perjuangan ikut menyalurkan duit haram itu untuk pemenangan beberapa calon dalam pemilihan kepala daerah yang baru usai" kalimat yang ada cukup lugas. Nama partai yang terlibat yaitu Partai Demokrasi Indonesia Perjuangan disebutkan langsung tanpa 
menggunakan pronomina yang lainnya. Tentunya dibutuhkan keberanian dalam memilih kosa kata yang cukup vulgar tanpa harus membuat para pembaca memprediksi dan menginterpretasi dengan imajinasi yang dimiliki. Kemudian kata "duit haram" adalah sebuah frasa yang cukup serius dalam mengungkapkan kekecewaan pada partai rezim atau penguasa. Kemudian kata "Fungsionaris Partai" merupakan kata yang dipilih untuk ditujukan pada orang-orang yang memiliki jabatan penting di Partai Demokrasi Indonesia Perjuangan pada hari ini. Entah mereka adalah ketua umum partai, penasihat partai atau bahkan mungkin saja para wakil rakyat yang sedang membawa aspirasi rakyat di kursi legislatif. Teks diatas menunjukan bentuk penegasan dari kekecewaan yang dirasakan rakyat, dalam hal ini wartawan Tempo berhasil mewakili isi hati rakyat kecil dengan tulisannya.

Pada kalimat berikutnya dapat kita lihat bagaimana wartawan Tempo seolah memaksakan Komisi Pemberantasan Korupsi dengan kalimat sebab akibat "Karena itu, penahanan Juliari pada 6 Desember lalu harus dijadikan pintu masuk untuk mengungkap lebar jejaring pelaku korupsi dana bansos". Terdapat hubungan perluasan dari kalimat ketiga tentang partai yang memiliki andil dalam kasus ini pula. Kalimat yang seolah memaksa juga diselaraskan dengan kalimat yang berikutnya yaitu "untuk mengungkap lebar jejaring pelaku korupsi dana bansos". Penggunaan konjungsi "karena" juga dapat berarti memberikan sebuah solusi atau jalan keluar dari kalimat-kalimat yang telah terkonstruksi dengan baik sebelumnya. Wartawan Tempo meminta Komisi Pemberantasan Korupsi untuk tidak diam dan berhenti pada kasus yang menyeret menteri Juliari.

Alur wacana yang dibangun oleh wartawan Tempo cukup menarik "KPK tidak boleh gentar, meski berhadapan dengan partai penguasa" kalimat yang terkesan harap-harap cemas dengan kapasitas yang dimiliki oleh Komisi Pemberantasan Korupsi. Meski demikian secara umum diksi "tidak boleh gentar" merupakan sebuah modalitas yang cenderung intensional atau dapat 
disebut juga dengan harapan besar yang diberikan kepada Komisi Pemberantasan Korupsi. Pronominal subjek pengganti yang kembali digunakan adalah "partai penguasa" secara tidak langsung kalimat yang ada ditujukan langsung kepada Partai Demokrasi Indonesia Perjuangan. Labelling yang dibangun oleh wartawan Tempo melalui diksi-diksi vulgarnya tentu akan membuat kesan negatif bagi Partai Demokrasi Indonesia Perjuangan sendiri.

Kalimat selanjutnya yang dibangun oleh wartawan Tempo "Korupsi dana bantuan untuk masyarakat yang terempas krisis ekonomi akibat pandemi jelas merupakan kejahatan level tertinggi”. Ini merupakan kalimat ekstensi atau penambahan dari kalimat penguat sebelumnya. Kalimat ini mengajak pembaca untuk dapat melihat kasus tindak pidana korupsi secara universal. Pemilihan kata "terempas" tentunya sangat beralasan. Makna secara bahasa yang berarti terbanting, tercampak merupakan kata yang cukup mengena di hati para pembaca. Kondisi perekonomian masyarakat yang tidak kunjung membaik di masa pandemi covid seharusnya memang benar-benar menjadi fokus penguasa. Pemilihan kata "kejahatan level tertinggi" merupakan kalimat tendensius yang dituliskan wartawan Tempo. Hal ini dilakukan sebenarnya untuk menunjukkan betapa bahaya dan kejamnya kasus korupsi yang dilakukan oleh menteri Juliari. Selain itu, semua ini adalah upaya berbeda yang dilakukan oleh media Tempo untuk mencerdaskan pembaca dengan tulisan-tulisannya. Tentu saja idealisme yang dibangun oleh media Tempo memberikan nuansa wacana berita yang berbeda dengan media lainnya.

Perluasan kalimat yang dilakukan oleh wartawan Tempo melalui kalimat "Karena itulah berbagai tanda ketidakberesan penyaluran bantuan sosial seolah-olah diabaikan begitu saja. Sistem pencegahan korupsi tak berjalan" benar-benar sangat dirasakan oleh para pembaca. Kata "ketidakberesan" dilanjutkan dengan kata "tidak berjalan" yang keduanya adalah kalimat pasif yang setara, kedua kalimat yang ada merupakan sebagai 
penegasan bahwa kontrol presiden selaku penguasa dalam menunjuk para menteri, mengawasi para menteri dari tindakan penyelewengan kekuasaan masih sangat lemah. Proses elaborasi yang dilakukan dari kalimat "ketidakberesan" menuju kalimat "tidak berjalan"sudah sangat baik. Dengan kata lain dua kalimat yang ada juga memiliki posisi sebagai frasa repetisi (pengulangan). Tujuannya adalah untuk dapat menguatkan pesan yang disampaikan oleh wartawan selaku penulis.

Dalam kalimat penutup, wartawan Tempo juga tidak lupa memberikan apresiasi kepada Komisi Pemberantasan Korupsi dengan kalimat "Publik patut mengapresiasi kerja keras penyidik komisi antikorupsi yang telaten mengumpulkan bukti demi bukti yang berujung pada penahanan Juliari”. Kalimat yang dibangun menunjukkan bahwa adanya hubungan kuat antara penangkapan menteri Juliari dengan tingkat profesionalitas kerja KPK. Dengan kata lain digunakan pula hubungan sebab akibat dalam kalimat yang ada. Disebabkan penyelidikan oleh KPK selaku lembaga independen hingga mengakibatkan menteri Juliari ditahan. Konstruksi kalimat yang dibangun oleh wartawan Tempo tentu untuk menunjukkan betapa pentingnya KPK dalam kasus ini.

Dengan demikian dapat dilihat bagaimana media Tempo dalam membangun citra KPK dalam pewartaan kasus korupsi yang menjerat menteri Juliari, secara umum kata demi kata hingga kalimat yang terkonstruksi dalam wacana yang ada menunjukan citra yang sangat positif. Diksi yang dipilih menunjukkan keseriusan media Tempo menjadi media pengungkap fakta-fakta yang telah terjadi, sehingga tidak memperdulikan hangat atau tidaknya tulisan yang ada. Kalimat-kalimat yang terkesan tendensius, emosional dan memprovokasi tentunya membuat gairah para pembaca untuk menyelesaikan bacaannya, pronomina atau kata ganti yang digunakan juga cukup menggelitik para pembaca. Tentulah gaya penulisan 
wartawan Tempo yang cukup vulgar ini mungkin saja tidak dapat diterima oleh semua kalangan pembaca.

Setelah dilakukan analisis tentang bagaimana media online Republika edisi 09 Desember 2020 dan Tempo edisi 19 Desember 2020 dalam membangun citra KPK dapat ditarik kesimpulan bahwa media Republika memberikan citra yang negatif terhadap KPK selaku lembaga pemberantasan korupsi. Adapun media Tempo mewartakan KPK dengan citra yang cukup positif. Kalimat-kalimat yang terkesan tendensius dan menyerang oleh Tempo tentunya sebagai gambaran bahwa Tempo memiliki ideologi yang berseberangan. Disisi lain juga terlihat bahwasanya idealisme media Tempo cukup tinggi dalam menghasilkan sebuah teks wacana. Adapun Republika terus mencoba membuat bacaan dengan bahasa yang hangat sehingga dapat diterima oleh berbagai kalangan.

Melalui dimensi tekstual, analisis dilakukan lewat tahapan representasi. Tahap representasi dipilah antara representasi dalam anak kalimat (klausa), representasi dalam kombinasi anak kalimat (klausa) dan representasi antarkalimat. Bagian representasi anak kalimat dianalisis lewat pemilihan kosa kata dan frasa yang dikonstruksikan wartawan melalui wacana yang ada. Representasi dalam kombinasi anak kalimat menitik beratkan pada kohesi dan koherensi dalam kalimat. Adapun kohesi yang digunakan adalah kata ganti (pronomina) dan juga kata pengulangan (repetisi). Lebih mendalam lagi, koherensi terdiri dari elaborasi (penjelasan), ekstensi (penambahan) dan juga hubungan perluasan. Pada tingkatan analisis representasi antarkalimat ditinjau dari kalimat yang lebih dikedepankan dengan kalimat yang lainnya.

\section{Praktik Kewacanaan}

Pada tahapan kedua dalam analisis Fairclogh adalah praktik wacana atau praktik kewacanaan. Dimana pada dimensi ini akan ditinjau bagaimana sebuah teks diproduksi yang tentu saja akan banyak membahas tentang wordview media atau wartawan sendiri sebagai subjek yang mengkonstruksikan 
wacana. Kemudian bagaimana teks atau produk hasil wacana yang ada dapat dikonsumsi, dengan kata lain siapakah khalayak yang menjadi objek sasaran wacana yang ada. Pada tahapan praktik kewacanaan pula dilihat bagaimana proses pendistribusian teks wacana yang ada sehingga memungkinkan gagasan serta opini wartawan dapat diterima.

Media Republika secara historis memiliki hubungan kedekatan dengan rezim atau penguasa pada hari ini. Hal ini memang tidak dapat dipungkiri karena kedekatan yang ada sedikit banyaknya akan mempengaruhi produk wacana yang dihasilkan. Sebagai media tentunya Republika tidak dapat melepaskan dirinya dari kepentingan siapa pemilik atau bahkan siapa yang menanamkan modal di dalamnya. Kepentingan yang ada juga tentunya beragam, terdapat kepentingan korporasi atau bisa saja penggiringan opini publik untuk dapat mendongkrak atau mengharumkan nama sebuah lembaga maupun institusi yang ada. Dalam hal ini KPK yang memiliki peran dalam pemberantasan korupsi tentunya akan menjadi lembaga yang sedikit banyaknya akan berseberangan dengan kepentingan rezim atau penguasa. Terlebih kasus korupsi yang melibatkan menteri sosial Juliari Batubara, tentunya akan dikaitkan dengan presiden selaku pemegang kekuasaan dalam memilih dan memberhentikan para menteri.

Dari awal lahirnya media Republika di Indonesia memang dikenal dengan media yang konsisten mampu menghidupkan wacana-wacananya dengan bernafaskan nilai-nilai Islam. Republika sangat dikenal karena konsistensinya dalam mengakomodasi suara umat Islam di dalamnya. Republika pula dikenal dengan media yang mampu mempertahankan idealisme dengan ciri yang khasnya sejak awal berdiri. Mulai dari pemilihan kata sampai dengan substansi yang ada memang dikenal sangat santun dan lugas oleh para pembaca.

Bermula dari goyahnya kedudukan politik pada masa rezim presiden Soeharto Republika mulai terbit pada tahun 1993 yang digagas oleh ICMI 
(Ikatan Cendekiawan Muslim Indonesia) dengan besaran saham $51 \%$ dari total jumlah saham yang dimiliki (Keller, 2009). Hal ini bertujuan untuk mengakomodasi kepentingan umat Islam yang semakin menunjukkan kemajuannya dari hari ke hari. Adapun tokoh besar pendiri dari Republika adalah presiden BJ. Habibie yang memang dikenal dekat dengan umat Islam. Kebangkitan kelompok Islam inilah yang dimanfaatkan oleh presiden Soeharto untuk tetap mempertahankan posisinya sebagai presiden yang pada waktu itu telah mengalami krisis kepercayaan dari masyarakat Indonesia.

Menariknya Republika di masa awal tidak terlalu mementingkan materi atau keuntungan dalam proses pemberitaan, hal inilah yang menyebabkan kepercayaan masyarakat semakin kuat. Akan tetapi setelah rezim pemerintahan presiden Soeharto dan pemerintahan presiden BJ. Habibie berakhir pada masa itu maka popularitas Republika mengalami penurunan, akhirnya ICMI (Ikatan Cendekiawan Muslim Indonesia) selaku penggagas Republika mengambil sikap. Sejak tahun 2000 Erick Thohir dengan korporasinya grup Mahaka menguasai mayoritas saham Republika hingga saat sekarang ini. Sedikit berubah rubrik dan halaman tabloid yang ditampilkan oleh Republika. Namun tetap mempertahankan ciri khas dari Republika sendiri, kini disediakanlah ruang bagi penulis lainnya seperti para mahasiswa untuk dapat berkontribusi melalui artikel yang diberi nama artikel Hikmah.

Salah satu alasan terkuat Erick Thohir membeli saham Republika tidak lain adalah untuk kepentingan bisnis. Erick menganggap peluang Republika sebagai media hiburan dan memegang peranan sebagai bisnis media di masa depan sangat menjanjikan (Keller, 2009). Kendatipun orientasi dari Republika cenderung sedikit berubah akan tetapi jika ada tindakan korupsi atau pelanggaran hukum tentunya akan tetap diberitakan. Dalam hal ini metode yang dikedepankan adalah metode pemberitaan yang tidak menyerang, tidak menghakimi meskipun itu memiliki kaitan erat dengan 
kepentingan. Sasaran berita yang dituju oleh Republika adalah para pembaca muslim, tentunya dapat dilihat dari diksi-diksi yang dipilih cenderung memilih nilai kebaikan universal, nilai kemanusiaan dan nilai demokratis. Tidak menunjukkan keberpihakan pada kelompok Islam tertentu sehingga wacana yang ada tetap dapat dinikmati oleh seluruh kalangan.

Erick Thohir adalah orang yang sangat berpengaruh pada pemerintahan periode kedua presiden Joko Widodo. Ia ditunjuk sebagai menteri BUMN (Badan Usaha Milik Negara) usai pilpres 2019. Erick Thohir juga merupakan tokoh penting dalam TKN (Tim Kampanye Nasional) presiden pada pemilihan 2019 silam. Erick Thohir tentunya memiliki hubungan yang tidak biasa dengan pemerintah. Tidak mengherankan apabila Republika yang sahamnya dikuasai oleh Erick Thohir akan menunjukkan konstruksi wacana yang positif bagi pemerintah. Citra negatif yang ditujukan kepada KPK selaku lembaga pemberantasan korupsi dari bangunan wacana Republika edisi pemberitaan Desember 2020 silam adalah sebagai bentuk defensif dari tekanan berbagai pihak kepada rezim atau penguasa. Dengan demikian upaya-upaya untuk melemahkan KPK tampak semakin terang benderang. Hal ini tampak semakin jelas pasca disahkannya hasil revisi UU KPK yang belum lama oleh DPR dan Presiden, banyak penolakan yang dilakukan oleh massa karena DPR dan Presiden dianggap tidak benar-benar menyerap aspirasi masyarakat (Santika, 2020).

Setelah mengkaji Republika secara komprehensif hingga ditemukan bagaimana wacana Republika membangun citra negatif bagi KPK, maka perlu diketahui pula bagaimana media Tempo membangun citra positif bagi KPK selaku lembaga yang memiliki fungsi pemberantasan korupsi di Indonesia. Secara historis Tempo pada awal mula juga menjadi bagian yang tidak dapat dipisahkan dari corong pemberitaan yang dimanfaatkan oleh rezim presiden Soeharto pada masa orde baru. Masa dimana media dikenal sebagai alat strategis yang digunakan untuk mempertahankan popularitas bagi 
kepentingan-kepentingan pemerintah dan juga kepentingan kelompok elite pemerintah. Tempo mulai eksis dalam pewartaan berita dengan gaya majalahnya pada tahun 1971. Akan tetapi seiring berkembangnya persaingan pewartaan media yang semakin kritis di masa itu, akhirnya Tempo menemukan ideologinya sendiri dengan melepaskan keterikatan yang ada dengan pemerintah masa itu (Keller, 2009).

Berubahnya haluan menjadi media kritis dan juga media yang mencerdaskan para pembaca bukanlah tantangan yang mudah bagi Tempo untuk tetap mempertahankan eksistensinya. Tekanan dari internal redaksi dan juga dari eksternal media kerap terjadi. Jiwa kritis salah satu penggagas dan selaku komisaris utama Tempo pada masa awal yakni Goenawan Mohamad tentunya menjadi hal yang paling disoroti pada masa rezim Soeharto. Beritaberita yang ditulis menurut penguasa kala itu cukup berbahaya dengan gaya investigasi dan bahasa vulgarnya dalam pemberitaan. Kini sumber tekanan tidaklah berhenti akan tetapi tekanan yang datang bukan lagi bersumber dari rezim dan militer, Tempo menjadi media yang paling sering mendapatkan pengaduan-pengaduan dari aktor masyarakat. Boleh jadi karena sebab kelugasan pemberitaan atau gaya penulisan berita yang bertujuan menarik minat pembaca

Satu hal yang menjadi alasan independensi yang mampu dipertahankan oleh Tempo tidak lain adalah perihal kepemilikan modal di dalamnya. Kepemilikan modal yang terpusat pada satu tangan sangatlah memungkinkan terjadinya intervensi sang pemilik modal di dalamnya, baik dalam hal pemilihan tema maupun substansi pemberitaan. Saham Tempo tidak dikuasai oleh korporasi-korporasi tertentu yang memungkinkan keberpihakan pemberitaan pada sang pemilik modal. Akan tetapi sekitar lebih dari 50\% saham Tempo dikendalikan oleh yayasan-yayasan yang membuat Tempo mampu bertahan dengan karakteristiknya yang khas, hal ini tetap dipertahankan dengan tujuan menjaga kepercayaan para pembaca. Proses 
investigasi yang mendalam dalam menggali setiap berita merupakan prinsip yang terus dipertahankan Tempo hingga hari ini. Grafik-grafik informasi yang tidak ketinggalan di dalamnya membuat berita yang disampaikan sangat logis dan masuk akal (Keller, 2009). Headline yang ditampilkan oleh Tempo dalam majalah edisi harian maupun mingguan sangatlah berkelas, tentunya semua ini dibuat sebagai pembeda karakteristik media Tempo dengan media yang lainnya. Misalnya saja beadline dalam kasus korupsi bansos yang menjerat Menteri Juliari Batubara, head line yang dibuat sangat menggelitik para pembaca dengan gambar tote bag dengan bertuliskan "Korupsi Bansos Kubu Banteng”. Dibutuhkan keberanian untuk mempertahankan opini yang dibangun tentunya dengan bukti-bukti dan kebenaran hasil investigasi.

Berbeda dengan media lainnya dimana pemilik modal memiliki peran besar dalam mengatur substansi berita, kini Tempo hadir dengan menjunjung tinggi nilai-nilai pers yang memberikan keleluasaan wartawan untuk mengikuti idealismenya. Nilai yang dipegang teguh oleh wartawan Tempo adalah prinsip "watchdog" sebagai mata dan telinga pemberi isyarat tandatanda. Pemimpin redaksi memiliki kuasa untuk mendukung bahkan meminta pertanggungjawaban wartawan sehingga redaksi memiliki self regulation yang diaturnya sendiri. Menurut pandangan Tempo, mempertahankan narasumber eksklusif merupakan bagian yang sangat penting dalam proses investigasi suatu berita. Hal ini sering menyebabkan bahaya keberpihakan wartawan. Namun bagi wartawan Tempo tidak selalu dituntut untuk bersikap netral, akan tetapi setiap wartawan ditekankan untuk mampu memberikan keseimbangan keseluruhan pemberitaan yang ada (Keller, 2009).

Gaya pemberitaan yang berbeda dari Tempo tentunya memiliki sasaran pembaca sendiri, mayoritas para pembaca Tempo adalah orang-orang yang berusia 20-44 tahun. Tempo bertekad menjadi ujung tombak modernisasi masyarakat Indonesia sebagai media yang progresif dan demokratis. Dengan demikian mereka para pembaca adalah orang-orang yang 
memang melihat langsung perubahan iklim politik yang ada di Indonesia sejak orde baru hingga kini masa reformasi. Para pembaca adalah orang yang memiliki idealisme yang tinggi untuk memperoleh berita yang memang benar-benar teruji kebenarannya.

Komitmen Tempo untuk menuangkan opini-opini logis dan kritis dalam konstruksi wacana yang ada merupakan usaha untuk mencerdaskan kehidupan berbangsa. Citra positif yang dibangun Tempo terhadap KPK pada pemberitaan kasus korupsi yang menjerat menteri Juliari Batubara merupakan bukti konsistensi tempo untuk mengungkapkan siapa pihak yang memiliki peran dalam kasus korupsi dana bansos di tubuh kementerian sosial. Apresiasi yang diberikan Tempo kepada KPK dalam konstruksi wacana edisi Desember 2020 kasus menteri Juliari bukan berarti untuk melemahkan pemerintah. Akan tetapi hal ini bertujuan untuk memperjuangkan pers yang mampu menakar kebenaran tanpa pandang bulu.

Dalam praktik kewacanaan diatas dapat dilihat bagaimana sebuah teks wacana dihasilkan. Media Republika dengan prinsip media yang bernafaskan Islam menunjukkan nilai-nilai demokratis, tidak memihak sehingga dengan harapan besar wacana yang dibangun dapat diterima oleh berbagai kalangan. Kepemilikan saham Erick Thohir dalam media Republika hingga hari ini besar kecilnya mempengaruhi substansi pemberitaan yang ada. Berbeda halnya dengan Tempo yang selalu menunjukkan wacana-wacana idealisnya dengan prinsip mempertahankan kebebasan pers. Penguasaan saham yang tidak berpusat pada perseorangan membuat substansi wacana yang ada tidak mementingkan diterima atau ditolaknya suatu wacana yang dihasilkan. Proses investigasi dan kebenaran dalam mengungkap fakta merupakan bagian yang terpenting dalam sebuah pemberitaan bagi Tempo. 


\section{Dimensi Sosiokultural}

Dimensi sosiokultural merupakan tahapan ketiga pada analisis wacana kritis Fairclogh, pada tahapan ini wacana akan dianalisis mulai dari tingkatan level situasional, institusional, dan level sosial.

\section{Situasional}

Pada level situasional Fairclogh memberikan fokus kepada konteks atau keadaan yang terjadi. Dalam hal ini bangunan wacana Republika dan Tempo diatas tidak dapat dipisahkan dari situasi politik yang sedang dialami oleh negara Indonesia. Republika memberikan citra negatif bagi KPK selaku lembaga yang menangani persoalan korupsi di Indonesia. Sedangkan Tempo memberikan citra positif bagi KPK dengan mengapresiasi kerja keras lembaga penyidik KPK dari kasus-kasus korupsi yang belum lama diungkap. Menurut pandangan Fairclogh, penguasa dalam hal ini menggunakan media Republika sebagai corong pemberitaan untuk tetap menjaga kepercayaan publik.

Pemberitaan yang minim dan miring terhadap KPK merupakan usaha untuk melemahkan lembaga pemberantasan korupsi di Indonesia. Usaha pelemahan ini juga dibuktikan dengan keputusan pemerintah untuk mengesahkan UU KPK pada September 2019 silam yang cenderung memberikan ruang bagi para koruptor yang ada di Indonesia. Kemudian peristiwa penangkapan menteri sosial Juliari Batubara dalam kasus korupsi bansos juga tidak jauh berselang dengan penangkapan Edi Prabowo selaku menteri kelautan dan perikanan. Situasi diataslah yang membuat Republika membangun citra negatif bagi KPK, sedangkan Tempo membangun citra positif bagi KPK dengan bahasa vulgarnya untuk mendorong penyelesaian kasus korupsi menteri Juliari Batubara.

\section{Institusional}

Pada level institusional Fairclogh memberikan fokus kepada aspek yang lebih luas yaitu pada objek terkait dalam pemberitaan. Dapat berupa 
sistem politik maupun sistem sosial masyarakat. Pada saat teks wacana diproduksi bulan Desember 2020 silam, keadaan perpolitikan di Indonesia memang sedang mengalami kegaduhan. Keadilan pemerintah benar-benar sedang diuji dengan berbagai permasalahan yang dihadapkan. Pandemi covid yang belum lagi berakhir, kasus penembakan anggota FPI hingga terungkapnya kasus korupsi yang melibatkan partai penguasa.

Banyaknya permasalahan yang ada di negeri ini tentunya akan mempengaruhi wajah pemberitaan yang ada di media. Tempo tidak segansegan memberikan beadline yang berbeda dengan media lainnya karena Tempo tidak memiliki kepentingan dengan penguasa, misalnya saja seperti "Korupsi Bansos Kubu Banteng”kemudian "Jatah Madam Bebas Potongan” dan dengan headline lainnya secara terang-terangan menekankan partai penguasa yaitu Partai Demokrasi Indonesia Perjuangan yang didirikan oleh Megawati Soekarno Putri. Oleh karenanya Tempo memberikan apresiasi kepada KPK karena mampu mengungkap fakta-fakta yang ada. Berbeda dengan Republika yang terus memberikan pembelaan dan pemakluman terhadap kasus korupsi di Indonesia yang telah dianggap sebagai budaya pejabat.

\section{Sosial}

Pada level sosial ini akan memberikan fokus yang lebih luas terkait ketidakadilan dan kesenjangan yang terjadi di masyarakat luas. Kondisi pandemi covid yang tidak kunjung membaik harusnya meningkatkan inisiatif pemerintah untuk bergegas mencarikan solusi yang cepat dan tepat untuk semua kalangan. Korupsi dana bansos yang melibatkan partai penguasa tentunya menimbulkan kekecewaan yang mendalam bagi masyarakat Indonesia. Partai yang memiliki porsi suara yang cukup besar di lembaga legislatif kini mengecewakan rakyat Indonesia. Partai yang mengklaim sebagai "partai wong cilik" kini lebih bejat dan biadab dari partai lainnya. Bagaimana tidak, keterlibatan petinggi dan elite partai PDI Partai Demokrasi Perjuangan menunjukkan bahwa korupsi yang dilakukan bukanlah dalam skala yang 
main-main jumlahnya. Ditambah lagi isu keterlibatan Gibran Rakabuming anak sulung Jokowi dalam pengadaan goodie bag atau tas jinjing pembungkus bansos yang akan diberikan pada masyarakat penerima bantuan semakin menimbulkan pertanyaan yang besar di hati masyarakat.

Pengadaan bansos yang seharusnya mendongkrak kondisi perekonomian masyarakat kini membuat luka baru, terlihat jelas bagaimana kepentingan politik mempermainkan media dan pemberitaan di masyarakat. Kondisi negara yang sedang tidak baik-baik saja seharusnya membuat pemerintah segera berbenah dari kejadian-kejadian yang baru saja terjadi. Media sudah seharusnya mengambil peran sebagai kontrol dan pengingat bagi penguasa.

\section{PENUTUP}

Berdasarkan analisis yang dilakukan dalam pembentukan citra KPK (Komisi Pemberantasan Korupsi) dalam penanganan kasus menteri Juliari Batubara pada pemberitaan media online Tempo dan media online Republika yang dianalisis menggunakan pendekatan Fairclogh ditemukan beberapa kesimpulan.

Pertama, Dalam dimensi tekstual Republika memberikan citra negatif bagi KPK selaku lembaga pemberantasan korupsi, hal ini dibuktikan dengan tidak disebutkannya lembaga KPK dalam konstruksi wacana yang ada. Sedangkan Tempo memberikan citra positif bagi KPK terhadap keberhasilannya dalam mengungkap kasus korupsi yang berskala besar, hal ini dibuktikan dengan kalimat "Publik patut mengapresiasi kerja keras penyidik komisi anti korupsi" menunjukkan bahwa Tempo mendukung KPK dalam mengusut tuntas kasus korupsi yang menjerat menteri Juliari.

Kedua Dalam praktik kewacanaan ditemukan bahwa Republika memiliki kedekatan dengan pemerintah, tentunya pemberitaan miring yang melibatkan pejabat pemerintah akan berusaha dikonstruksikan dengan wacana yang lebih santun. Sedangkan Tempo yang tidak memiliki hubungan 
kedekatan dengan pemerintah akan berjuang menyuarakan pers yang mencerdaskan.

Ketiga, dalam dimensi sisiokultural ditemukan bahwa upaya pelemahan KPK dengan diberlakukannya revisi RUU KPK 2019 mengakibatkan kontsruksi wacana Rebublika bagi citra KPK cenderung negatif. Sedangkan Tempo memberikan citra positif bagi KPK karena telah mampu mengungkap korupsi yang menyengsarakan rakyat.

\section{DAFTAR REFERENSI}

Brossard, D., \& Scheufele, D. A. (2013). Science, new media, and the public. Science, 339(6115), 40-41. https://doi.org/10.1126/science.1232329

Fairclough, N. (2010). Critical discourse analysis: the critical study of language / Norman Fairclough. In Critical discourse analysis: the critical study of language.

Jangan Berhenti di Menteri juliari. (2020). Majalah.Tempo.Co.

Keller, A. (2009). Tantangan dari Dalam, Otonomi Redaksi di 4 Media Cetak Nasional: Kompas, Koran Tempo, Media Indonesia, Republika. Media.

Mensos Korupsi Dana Bansos, Budaya Pejabat Negara. (2020). Republika.Co.Id.

Munfarida, E. (1970). Analisis Wacana Kritis Dalam Perspektif Norman Fairclough. KOMUNIKA: Jurnal Dakwah Dan Komunikasi, 8(1), 1-19. https://doi.org/10.24090/komunika.v8i1.746

Prabawati, G. (2020). 4 Menteri Jokowi yang jadi Tersangka Korupsi, Terbaru Mensos Juliari P Batubara. Tribunnews.Com.

Santika, I. G. N. (2020). Menelisik Akar Kegaduhan Bangsa Indonesia Pasca Disetujuinya Hasil Revisi UU KPK Dalam Perspektif Pancasila. Jurnal Ilmiah Ilmu Sosial, 6(1), 26. https://doi.org/10.23887/jiis.v6i1.25001 